\title{
A PEG 4000-degrading and hexavalent molybdenum-reducing Pseudomonas putida strain Egypt-15
}

\author{
M. Abd. AbdEl-Mongy1 ${ }^{1}$ S.A. Aqlima², M.S. Shukor ${ }^{3}$, S. Hussein ${ }^{4}$, A.P.K. Ling ${ }^{5 *}$ and M.Y. Shukor ${ }^{2,3}$ \\ ${ }^{\prime}$ Microbial Biotechnology Department, Genetic Engineering and Biotechnology Institute, Sadat City University, Egypt. \\ ${ }^{2}$ Department of Biochemistry, Faculty of Biotechnology and Biomolecular Sciences, Universiti Putra Malaysia, Selangor, Malaysia. \\ ${ }^{3}$ Snoc International Sdn Bhd, Lot 343, Jalan 7/16 Kawasan Perindustrian Nilai 7, Inland Port, 71800, Negeri Sembilan, Malaysia. \\ ${ }^{4}$ Malaysian Nuclear Agency, Agrotechnology and Bioscience Division, Bangi, Malaysia. \\ ${ }^{5}$ Division of Applied Biomedical Sciences and Biotechnology, School of Health Sciences, International Medical University, Kuala Lumpur, Malaysia.
}

Revised: 26 February 2018; Accepted: 28 March 2018

\begin{abstract}
The objectives of this work were to isolate and characterise a heavy metal-reducing bacterium with the capability to degrade another xenobiotic; an organic pollutant. Six molybdenum-reducing bacteria from soil that can reduce sodium molybdate into the colloidal molybdenum blue (Mo-blue) were isolated. One of these isolates identified as Pseudomonas putida strain Egypt-15 was capable of growing on PEG 4000. The optimal conditions for Mo-blue production were $34{ }^{\circ} \mathrm{C}$, pH $6.5,20 \mathrm{mM}$ molybdate, and glucose as the electron donor. The optimum concentration supporting the growth on PEG 4000 was between 600 and $800 \mathrm{mgL}^{-1}$. PEG degradation showed a lag period of about two days and $75 \%$ degradation of PEG 4000 was achieved on day six at $800 \mathrm{mgL}^{-1}$. Growth on PEG 4000 at $800 \mathrm{mgL}^{-1}$ modelled according to the modified Gompertz model gave a maximum specific growth rate of $2.216 \mathrm{~d}^{-1}$ and a lag period of 1.45 days. Growth on PEG was optimum at $30{ }^{\circ} \mathrm{C}$ and $\mathrm{pH}$ 7.5. The dual ability of this bacterium to detoxify molybdenum and degrade PEG is novel and will be very useful for bioremediation.
\end{abstract}

Keywords: Modified Gompertz, molybdenum blue, molybdenum-reducing bacteria, polyethylene glycol biodegradation, Pseudomonas putida strain Egypt-15.

\section{INTRODUCTION}

Industrial and mining activities of molybdenum are two major sources of molybdenum pollution worldwide. The principal molybdenum usage is for the alloy and steel industries. Areas near these industries have been reported to be contaminated with molybdenum. The Black Sea and the Japan Bay and soils from a grazing area of cattle in Austria (Neunhäuserer et al., 2001) are reported to be affected with molybdenum pollution. Aside from industrial activity, a more serious pollution of molybdenum is reported from mining activities. The highest concentration of molybdenum in the environment to date is about $6,500 \mathrm{mgKg}^{-1}$ (approximately $68 \mathrm{mM}$ ) from an abandoned uranium mine (Stone \& Stetler, 2008). In Malaysia, molybdenum is produced in small quantities from copper mining. Although the mine has been abandoned for several years, its mine tailings and holding dams still contain elevated concentrations of toxic metal ions, polluting the surrounding ecosystems (Ali et al., 2006).

Molybdenum transformations into either insoluble molybdenum disulphide or to colloidal molybdenum blue (Mo-blue) are potential mechanisms for molybdenum bioremediation (Ghani et al., 1993). As the production of molybdenum disulphide results in the production of toxic hydrogen sulphide gas, bacterial transformation of molybdenum to Mo-blue is a better mechanism for the bioremediation of molybdenum as reduction occurs under near neutral $\mathrm{pH}$ and facultative conditions (Ghani et al., 1993). Numerous Mo-reducing bacteria have been isolated with Mo-reducing properties from the bacterial

\footnotetext{
*Corresponding author (anna_ling@imu.edu.my; (iD https://orcid.org/0000-0003-0930-0619)
} 
genera Klebsiella (Lim et al., 2012; Halmi et al., 2013; Masdor et al., 2015; Sabullah et al., 2016), Bacillus (AboShakeer et al., 2013; Othman et al., 2013), Pseudomonas (Shukor et al., 2010a; Ahmad et al., 2013), Enterobacter (Shukor et al., 2009a), Escherichia (Capaldi \& Proskauer, 1896; Campbell et al., 1985), Acinetobacter (Shukor et al., 2010b) and Serratia (Shukor et al., 2008b; Rahman et al., 2009; Shukor et al., 2009b; Yunus et al., 2009), and have been characterised.

Industries such as pharmaceutical, lubricant, cosmetic, and antifreeze are the main consumers of polyethylene glycol (PEG) and non-ionic surfactantbased PEGs. Several millions of tons of this compound are consumed and produced annually. PEGs are watersoluble polymers and have the common structural formula of $\mathrm{HO}\left(\mathrm{CH}_{2} \mathrm{CH}_{2} \mathrm{O}\right) \mathrm{nCH}_{2} \mathrm{CH}_{2} \mathrm{OH}$, which differ in their chain lengths and molecular weights. PEG with $\mathrm{n}=9$ possesses an average molecular weight of about 400 daltons, and the PEG is labelled as PEG 400 (TraversoSoto et al., 2016). The toxicity of PEG to mammals has been documented. PEG is a parasympathomimetic-like chemical. Wounded rabbits that are exposed topically to PEG-based antimicrobial cream showed that PEG absorption leads to symptoms of nephrotoxicity with several deaths after one week of exposure (Traverso-Soto, et al., 2016). Absorption of PEG into the bloodstream causes a fatal toxic syndrome through the formation of mono- and dicarboxylated forms (Traverso-Soto et al., 2016). Effluents contaminated with PEGs usually reach conventional sewage treatment systems making them a significant pollutant (Watanabe \& Kawai, 2010). PEG is a recalcitrant xenobiotic, and contamination of aquatic sediments in seas and rivers have been reported, and PEG degradation in these sediments are even slower. A study has shown that $5 \mathrm{mgL}^{-1}$ of various PEGs of up to PEG 400 require about 170 days to completely degrade a small concentration of PEG under anaerobic conditions (Traverso-Soto et al., 2016). In general, PEGs with longer carbon chains degrade more slowly than shorter chains. Chains longer than PEG 10000 are either slowly degraded anaerobically with incubation time in hundreds of days or in the presence of bacterial co-culture aerobically. The existence of higher chain-PEG-degrading monoculture (PEG 20000) bacteria are rare and a few exists (Watanabe \& Kawai, 2010). The principal PEG-degrading enzymes under aerobic conditions are alcohol dehydrogenase, aldehyde dehydrogenase and an ether-bond splitting enzyme that progressively oxidises PEG into carboxylic acid groups, eventually producing glyoxylate (GOA), which can be integrated into generic anabolic pathways starting from the glyoxylate shunt (Marchal et al., 2008; Watanabe \& Kawai, 2010).
Since rivers and soils receive effluents from many industries, contamination of the environment with heavy metals and toxic xenobiotics including molybdenum and PEG is anticipated. This presents a challenge for efficient bioremediation. The use of several microorganisms each displaying multiple detoxification attributes can reduce the cost of bioremediation. Hence, the focus of this research was to identify a microorganism with both heavy metal and xenobiotic detoxification property, with a distinctive focus on molybdenum as the model metal and PEG as the model xenobiotic. In this study, a molybdenum-reducing bacterium that can grow on PEG 4000 is first reported. In addition, the modified Gompertz model will be utilised to model the growth on PEGs to obtain important growth parameters. The multiple detoxification potential of this bacterium will be an important component of a battery of microbial degraders needed to cleanup multiple toxicant-containing polluted sites.

\section{METHODOLOGY}

\section{Site of soil sampling}

Ten grams of soil was taken from about $5 \mathrm{~cm}$ below the topsoil using a sterile large steel spatula and placed in a sterile polycarbonate container. The soil sample was taken from a riverbank land receiving agricultural run offs and industrial effluents in Sadat City, Egypt, in 2014.

\section{Molybdenum reducing low phosphate molybdate media}

The isolation of Mo-reducing bacterial candidates was carried out on a low phosphate minimal salts medium (MSM), which is also called low phosphate molybdate (LPM) medium. Another growth medium is the high phosphate molybdate medium or HPM, which is similar to the LPM but the phosphate concentration is increased to $100 \mathrm{mM}$ to prevent cell aggregation with the colloidal Mo-blue. Mo-reducing enzyme activity was similar either in LPM or HPM medium (Ghani et al., 1993; Shukor et al., 2008a; 2014). A soil suspension was initially prepared by mixing $1 \mathrm{~g}$ of soil with $10 \mathrm{~mL}$ of deionised water. Then, $0.1 \mathrm{~mL}$ of the soil suspension was spread onto a Petri dish containing LPM medium (w/v) at pH 6.5 with the following composition: $\mathrm{Na}_{2} \mathrm{MoO}_{4} \cdot 2 \mathrm{H}_{2} \mathrm{O}$ $(0.242 \%$ or $10 \mathrm{mM}), \mathrm{NaCl}(0.5 \%)$, agar $(1.5 \%)$, $\mathrm{MgSO}_{4} \cdot 7 \mathrm{H}_{2} \mathrm{O}(0.05 \%)$, glucose $(1 \%)$, yeast extract $(0.5 \%),\left(\mathrm{NH}_{4}\right)_{2} \cdot \mathrm{SO}_{4}(0.3 \%)$, and $\mathrm{Na}_{2} \mathrm{HPO}_{4}(0.071 \%$ or $5 \mathrm{mM}$ ) (Masdor et al., 2015). After $48 \mathrm{~h}$ of incubation at room temperature, 6 blue colonies appeared on the plate. 
The isolates were repeatedly transferred onto fresh LPM agar plates to purify the isolate for further screening on growth on various PEGs.

\section{Assay for Mo-blue production and scanning absorption spectrum}

Mo-blue production was quantified in a $100 \mathrm{~mL}$ liquid culture of LPM medium. This was carried out to choose the most efficient isolate. The culture supernatant was first centrifuged at $10,000 \mathrm{~g}$ for $5 \mathrm{~min}$ and the absorbance of the supernatant was read at $750 \mathrm{~nm}$. An extinction coefficient of $11.69 \mathrm{mM}^{-1} \mathrm{~cm}^{-1}$ at $750 \mathrm{~nm}$ was utilised to choose the best isolate (Masdor et al., 2015). The centrifuged culture supernatant was also scanned between 400 and $900 \mathrm{~nm}$ utilising LPM medium as the baseline correction.

\section{Identification of Mo-reducing bacterium}

The bacterium was identified based on phenotypical and biochemical methods as outlined in the Bergey's Manual of Determinative Bacteriology and computed into the ABIS online system as before (Masdor et al., 2015).

\section{Preparation of resting cells for Mo-blue production, characterisation and PEG screening}

Preparation of resting cells was carried out according to a previous method (Shukor et al., 2014). The bacterium was grown in $1 \mathrm{~L}$ of HPM on an orbital shaker $(120 \mathrm{rpm})$ at room temperature $\left(28^{\circ} \mathrm{C}\right)$ for $48 \mathrm{~h}$. Cells were centrifuged for $10 \mathrm{~min}$ at $10,000 \mathrm{~g}$, and the cellular pellets were then washed twice with deionised water, followed by resuspension in $20 \mathrm{~mL}$ of LPM medium (glucose omitted initially) giving an optical density reading of about 1.0 at $600 \mathrm{~nm}$. The cell suspension prepared $(180 \mu \mathrm{L})$ was transferred to each well of a sterile microplate. Sterile glucose or other sugars as carbon sources $(20 \mu \mathrm{L})$ from a $10 \%(\mathrm{w} / \mathrm{v})$ stock solution was mixed with the cell suspension to initiate Mo-blue production. The microplate was covered with a sterile sealing tape to allow gas exchange (Corning ${ }^{\mathbb{B}}$ microplate). The microplate was incubated at room temperature and Mo-blue production was determined at $750 \mathrm{~nm}$ in a microtiter plate reader model no. 680 (BioRad, Richmond, CA). The specific extinction coefficient of $11.69 \mathrm{mM}^{-1} \mathrm{~cm}^{-1}$ was utilised to determine Mo-blue concentration (Shukor et al., 2003).

\section{Screening of PEGs as carbon sources for growth}

Preliminary studies show that none of the PEGs utilised in this work such as PEG 4000, PEG 5000, PEG 8000, PEG 10000, PEG 14000 and PEG 20000 (Sigma Aldrich,
USA) can support molybdenum reduction to Mo-blue. Thus, the various PEGs were tested for their ability to support growth instead. The study was carried out using the microplate format above in the growth medium below with PEGs utilised at a final concentration of $1000 \mathrm{mgL}^{-1}$ in a final volume of $250 \mu \mathrm{L}$. A $20 \mu \mathrm{L}$ cell suspension from the above resting cell preparation was added as an initial inoculum. The ingredients of the growth medium ( $\mathrm{pH}$ 7.0) were as follows: $\mathrm{NaNO}_{3}(0.2 \%),\left(\mathrm{NH}_{4}\right)_{2} \cdot \mathrm{SO}_{4}$ $(0.3 \%)$, yeast extract $(0.01 \%), \mathrm{MgSO}_{4} .7 \mathrm{H}_{2} \mathrm{O}(0.05 \%)$, $\mathrm{Na}_{2} \mathrm{HPO}_{4}(0.705 \%$ or $50 \mathrm{mM}), \mathrm{NaCl}(0.5 \%)$, and $1 \mathrm{~mL}$ of trace elements solution. The trace elements solution composition $\left(\mathrm{mgL}^{-1}\right)$ was as follows: $\mathrm{FeSO}_{4} \cdot 7 \mathrm{H}_{2} \mathrm{O}$ (40), $\mathrm{CaCl}_{2}(40), \mathrm{MnSO}_{4} \cdot 4 \mathrm{H}_{2} \mathrm{O}(40), \mathrm{CuSO}_{4} \cdot 5 \mathrm{H}_{2} \mathrm{O}(5)$, $\mathrm{ZnSO}_{4} \cdot 7 \mathrm{H}_{2} \mathrm{O}(20), \mathrm{Na}_{2} \mathrm{MoO}_{4} \cdot 2 \mathrm{H}_{2} \mathrm{O}$ (5) $\mathrm{CoCl}_{2} \cdot 6 \mathrm{H}_{2} \mathrm{O}$ (5). Bacterial growth was determined optically at $600 \mathrm{~nm}$ after five days of incubation at room temperature $\left(28^{\circ} \mathrm{C}\right)$ using the microplate reader (Bio-Rad 680).

\section{Assay for PEG}

PEG was determined through a colourimetric method that is sensitive, simple, and applicable to all PEG derivatives (Sims \& Snape, 1980). Stock solutions of various PEGs were prepared as $10 \mathrm{mgL}^{-1}$. The total volume of the mixture was $2 \mathrm{~mL}$ and consisted of stably diluted stock solutions of various PEGs to make the final concentration between 1 to $7.5 \mathrm{mgL}^{-1}$. Samples from the resting cell preparation were suitably diluted before being added to the assay reagents. Samples were taken at initial incubation and after an extended incubation period of $10 \mathrm{ds}$ at room temperature. The colour developing reagents consist of a $200 \mu \mathrm{L}$ solution of $5 \%(\mathrm{w} / \mathrm{v}) \mathrm{BaCl}_{2}$. $\mathrm{H}_{2} \mathrm{O}$ in $1 \mathrm{M} \mathrm{HCl}$ mixed with $200 \mu \mathrm{L}$ of a solution of $1.27 \mathrm{~g}$ iodine dissolved in $100 \mathrm{~mL}$ of $2 \%(\mathrm{w} / \mathrm{v})$ potassium iodide. Colour that developed after $10 \mathrm{~min}$ of incubation at room temperature $\left(28^{\circ} \mathrm{C}\right)$ was read at $535 \mathrm{~nm}$ against a reagent blank using water. The concentration of PEG was determined based on the formation of an intensity of brownish orange colour by the complex solution (Watanabe \& Kawai, 2010).

The percentage of PEG degradation was calculated as:

$\%$ PEG degradation $=\left[1-\left([\mathrm{PEG}] t_{f}[\mathrm{PEG}] t_{i}\right)\right] \times 100 \%$

where $[\mathrm{PEG}] t_{f}$ indicates the concentration of PEG at the time of final incubation, and [PEG] $t_{i}$ indicates the concentration of PEG at the time of initial incubation.

\section{Mathematical modelling of growth on PEG}

The modified Gompertz model (equation 2) (Gibson et al., 1987) is a robust model that can describe the growth 
of a bacterium on a multitude of substrates. The model was utilised to describe the growth of the bacterium on PEG 4000. The absorbance value at $600 \mathrm{~nm}$ was first converted to natural logarithm. This study was carried out in a scale-up version aerobically. The bacterium was grown aerobically on an orbital shaker $(120 \mathrm{rpm})$ at room temperature in $50 \mathrm{~mL}$ of culture media for this purpose. The initial bacterial inoculum was $1 \%(\mathrm{v} / \mathrm{v})$.

$y=A \exp \left\{-\exp \left[\frac{\mu_{m} e}{A}(\lambda-t)+1\right]\right\}$

where $A=$ bacterial growth at lower asymptote; $\mu_{m}=$ maximum specific bacterial growth rate, $\lambda=$ lag time, $e=$ exponent (2.718281828) and $t=$ sampling time.

The growth parameters $\mu_{m}$ and $\lambda$ were obtained using a nonlinear regression analysis employing the LevenbergMarquardt algorithm (LMA) through the CurveExpert Professional software (version 1.6). The algorithm minimises the sum of the squares of the differences between the measured and predicted values (Zwietering et al., 1990). In non-linear regression, a modified form of the coefficient of determination, the adjusted coefficient of determination $\left(a d j R^{2}\right)$ was utilised instead of the often used $R^{2}$, as the former takes into account the number of parameters of a model. The modified Gompertz model has 3 parameters to be solved. The formulae are as follows (equations 3 and 4), where RMS is the residual mean square and ${ }^{S_{y}}$ is the total variance of the y variable (Zwietering et al., 1990).

$$
\begin{aligned}
& \operatorname{Adjusted}\left(R^{2}\right)=1-\frac{R M S}{s_{Y}^{2}} \\
& \text { Adjusted }\left(R^{2}\right)=1-\frac{\left(1-R^{2}\right)(n-1)}{(n-p-1)}
\end{aligned}
$$

\section{Identification of the bacterium through 16S rDNA gene sequencing}

Bacterial genomic DNA was obtained through alkaline lysis. The 16S rDNA from the genomic DNA was amplified via PCR (Biometra, Montreal Biotech Inc., Kirkland, QC) using the following primers; 5'-AGAGTTTGATCCTGGCTCAG-3' and 5'-AAGGAGGTGATCCAGCCGCA-3' corresponding to the forward and reverse primers of $16 \mathrm{~S}$ rDNA, respectively (Devereux \& Willis, 1995). The 16S rRNA gene sequence of this bacterium (1447 bp) has been submitted to the DNA Data Bank of Japan under the accession number LC150887. Several 16S rRNA gene sequences of other bacterial isolates that closely matched this isolate were retrieved from GenBank and then aligned using the programme Clustal Omega. A bootstrapped phylogenetic tree was constructed utilising the suits of programmes in PHYLIP, version 3.573.

\section{RESULTS AND DISCUSSION}

The phenomenon of molybdenum reduction to Mo-blue is observed predominantly in heterotrophic bacteria from the Enterobacteriaceae family using minimal salts or complex media under low phosphate $(<10 \mathrm{mM})$ and elevated molybdate $(>10 \mathrm{mM})$ conditions (Campbell et al., 1985). Bacterial reduction of molybdate to Moblue was first mentioned more than a century ago in the year 1896 (Capaldi \& Proskauer, 1896). Intermittent or sporadic reports on this phenomenon since then reflects the rarity of this phenomenon (Campbell et al., 1985; Ghani et al., 1993). Of these reports, comprehensive studies were carried out by Campbell et al. (1985) on the bacterium Escherichia coli $\mathrm{K} 12$ and by Ghani et al. (1993) on the bacterium Enterobacter cloacae strain 48 (EC 48) with the latter quickly recognising the potential application of this phenomenon for molybdenum bioremediation. Table 1 shows the characteristics of Moreducing bacteria isolated to date.

\section{Selection of Mo-reducing bacterium exhibiting PEG degradation}

Six Mo-reducing bacterial candidates were isolated and then screened for growth on PEG. None of the PEGs tested could be used as electron donor for supporting molybdenum reduction (Table 2). The best candidate giving the highest Mo-blue was isolate $\mathrm{O}$ with 12.04 nmole Mo-blue produced after five days of incubation at room temperature. However, isolate $\mathrm{N}$ can reduce molybdenum and grow on PEG 4000 (Table 2), and it was chosen for further studies.

Microscopic analysis showed that the isolate was a Gramnegative, rod-shaped and motile bacterium. The results from the biochemical tests (Table 3) were then analysed using the ABIS online software. The two suggestions for the bacterial identity were Pseudomonas putida and P. monteilii with a similar homology score of $80 \%$ and an accuracy score of $85 \%$. A molecular identification technique through phylogenetic analysis of the $16 \mathrm{~S}$ rRNA gene was also carried out. The phylogenetic tree in Figure 1 shows the relationship between strain Egypt-15 and other closely related species. Strain Egypt-15 was closely related to P. putida with a high bootstrap value. 
Table 1: Characterisation of Mo-reducing bacteria isolated to date

\begin{tabular}{|c|c|c|c|c|}
\hline Bacteria & $\begin{array}{l}\text { Optimal } \\
\text { C source }\end{array}$ & $\begin{array}{l}\text { Optimal } \\
\text { molybdate } \\
(\mathrm{mM})\end{array}$ & $\begin{array}{l}\text { Heavy metals } \\
\text { inhibition }\end{array}$ & Author \\
\hline Klebsiella oxytoca strain Saw-5 & glucose & $20-30$ & $\begin{array}{l}\mathrm{Cu}^{2+}, \mathrm{Ag}^{+}, \mathrm{Hg}^{2+} \\
\mathrm{Cd}^{2+}\end{array}$ & (Sabullah et al., 2016) \\
\hline Pseudomonas aeruginosa strain Amr-11 & glucose & $20-30$ & $\begin{array}{l}\mathrm{Cd}^{2+}, \mathrm{Cr}^{6+}, \mathrm{Cu}^{2+}, \\
\mathrm{Ag}^{+}, \mathrm{Hg}^{2+}\end{array}$ & (Ibrahim et al., 2015) \\
\hline Klebsiella oxytoca strain Aft-7 & glucose & $5-20$ & $\mathrm{Cu}^{2+}, \mathrm{Ag}^{+}, \mathrm{Hg}^{2+}$ & (Masdor et al., 2015) \\
\hline Bacillus sp. strain A.rzi & glucose & 50 & $\begin{array}{l}\mathrm{Cd}^{2+}, \mathrm{Cr}^{6+}, \mathrm{Cu}^{2+}, \\
\mathrm{Ag}^{+}, \mathrm{Pb}^{2+}, \mathrm{Hg}^{2+}, \\
\mathrm{Co}^{2+}, \mathrm{Zn}^{2+}\end{array}$ & (Othman et al., 2013) \\
\hline Bacillus pumilus strain lbna & glucose & 40 & $\begin{array}{l}\mathrm{As}^{3+}, \mathrm{Pb}^{2+}, \mathrm{Zn}^{2+} \\
\mathrm{Cd}^{2+}, \mathrm{Cr}^{6+}, \mathrm{Hg}^{2+}, \\
\mathrm{Cu}^{2+}\end{array}$ & $\begin{array}{l}\text { (Abo-Shakeer et al., } \\
\text { 2013) }\end{array}$ \\
\hline Pseudomonas sp. strain DRY1 & glucose & $30-50$ & $\begin{array}{l}\mathrm{Cd}^{2+}, \mathrm{Cr}^{6+}, \mathrm{Cu}^{2+} \\
\mathrm{Ag}^{+}, \mathrm{Pb}^{2+}, \mathrm{Hg}^{2+}\end{array}$ & (Ahmad et al., 2013) \\
\hline Klebsiella oxytoca strain hkeem & fructose & 80 & $\mathrm{Cu}^{2+}, \mathrm{Ag}^{+}, \mathrm{Hg}^{2+}$ & (Lim et al., 2012) \\
\hline Pseudomonas sp. strain DRY2 & glucose & $15-20$ & $\begin{array}{l}\mathrm{Cr}^{6+}, \mathrm{Cu}^{2+}, \mathrm{Pb}^{2+} \\
\mathrm{Hg}^{2+}\end{array}$ & (Shukor et al., 2010a) \\
\hline $\begin{array}{l}\text { Acinetobacter calcoaceticus strain } \\
\text { Dr.Y12 }\end{array}$ & glucose & 20 & $\begin{array}{l}\mathrm{Cd}^{2+}, \mathrm{Cr}^{6+}, \mathrm{Cu}^{2+}, \\
\mathrm{Pb}^{2+}, \mathrm{Hg}^{2+}\end{array}$ & (Shukor et al., 2010b) \\
\hline Serratia marcescens strain Dr.Y9 & sucrose & 20 & $\begin{array}{l}\mathrm{Cr}^{6+}, \mathrm{Cu}^{2+}, \mathrm{Ag}^{+} \\
\mathrm{Hg}^{2+}\end{array}$ & (Yunus et al., 2009) \\
\hline Serratia sp. strain Dr.Y8 & sucrose & 50 & $\mathrm{Cr}, \mathrm{Cu}, \mathrm{Ag}, \mathrm{Hg}$ & (Shukor et al., 2009b) \\
\hline Enterobacter sp. strain Dr.Y13 & glucose & $25-50$ & $\begin{array}{l}\mathrm{Cr}^{6+}, \mathrm{Cd}^{2+}, \mathrm{Cu}^{2+} \\
\mathrm{Ag}^{+}, \mathrm{Hg}^{2+}\end{array}$ & (Shukor et al., 2009a) \\
\hline Serratia sp. strain Dr.Y5 & glucose & 30 & n.a. & (Rahman et al., 2009) \\
\hline Serratia marcescens strain DRY6 & sucrose & $15-25$ & $\mathrm{Cr}^{6+}, \mathrm{Cu}^{2+}, \mathrm{Hg}^{2+}$ & (Shukor et al., 2008b) \\
\hline Enterobacter cloacae strain 48 & sucrose & 20 & $\mathrm{Cr}^{6+}, \mathrm{Cu}^{2+}$ & (Ghani et al., 1993) \\
\hline Escherichia coli $\mathrm{K} 12$ & glucose & 80 & $\mathrm{Cr}^{6+}$ & (Campbell et al., 1985) \\
\hline
\end{tabular}

Hence, based on biochemical and molecular phylogeny results, the bacterium was assigned as Pseudomonas putida strain Egypt-15. Two previous Mo-reducing bacteria from this genus Pseudomonas sp. strain DRY2 (Shukor et al., 2010a) and the Antarctic bacterium Pseudomonas sp. strain DRY1 (Ahmad et al., 2013) have been reported. Pseudomonas spp. are well known PEG degraders (Pan \& Gu, 2007; Watanabe \& Kawai, 2010). Mo-blue production was optimum at $34{ }^{\circ} \mathrm{C}$ and pH 6.5 (data not shown). The use of a microplate format expedite and simplify PEG-screening processes as well as simplifying Mo-reduction characterisation (Shukor \& Shukor, 2014). The use of washed, whole or resting cells in studying xenobiotic detoxifications has been carried out in the characterisation of molybdenum reduction (Ghani et al., 1993) and also in PEG degradation studies (Kawai \& Yamanaka, 1989).

\section{Molybdenum absorbance spectrum}

The absorption spectrum of Mo-blue produced by P. putida strain Egypt-15 exhibited a maximum peak near the infrared region at $865 \mathrm{~nm}$ and a shoulder at $710 \mathrm{~nm}$ (Figure 2). The Mo-blue spectrum from this bacterium is very similar to the Mo-blue spectrum seen in the phosphate determination method (PDM) using ascorbic acid as a reducing agent. The PDM's Mo-blue spectrum has a maximum absorption between 880 and $890 \mathrm{~nm}$ and a shoulder between 700 and $720 \mathrm{~nm}$ (Clesceri et al., 1989). Incidentally, the entire Mo-blue spectra from other Mo-reducing bacteria are very similar (Shukor et al., 2007; Shukor \& Syed, 2010; Masdor et al., 2015; Sabullah et al., 2016). As the Mo-blue from the PDM method is a reduced phosphomolybdate, it is proposed that the identity of the Mo-blue from bacterial reduction of molybdate is also a reduced phosphomolybdate. 
Table 2: Growth on various PEGs measured as optical density increase at $600 \mathrm{~nm}$ and Mo-blue production after 5 days of incubation at room temperature. Absorbance increase of less than 0.075 absorbance unit at $600 \mathrm{~nm}$ was considered as no growth (-)

\begin{tabular}{|c|c|c|c|c|c|c|c|c|}
\hline Isolate & $\begin{array}{l}\text { nmole Mo-blue } \\
( \pm \text { standard deviation, } \\
\mathrm{n}=3) \text { on glucose }\end{array}$ & $\begin{array}{l}\text { nmole } \\
\text { Mo-blue } \\
( \pm \text { standard } \\
\text { deviation, } \\
\mathrm{n}=3) \text { on } \\
\text { PEG }\end{array}$ & $\begin{array}{l}\text { PEG } \\
4000\end{array}$ & $\begin{array}{l}\text { PEG } \\
5000\end{array}$ & $\begin{array}{l}\text { PEG } \\
8000\end{array}$ & $\begin{array}{c}\text { PEG } \\
10000\end{array}$ & $\begin{array}{c}\text { PEG } \\
14000\end{array}$ & $\begin{array}{c}\text { PEG } \\
20000\end{array}$ \\
\hline K & $8.13 \pm 0.02$ & - & - & - & - & - & - & - \\
\hline $\mathrm{L}$ & $9.43 \pm 0.03$ & - & - & - & - & - & - & - \\
\hline M & $10.24 \pm 0.04$ & - & - & - & - & - & - & - \\
\hline $\mathrm{N}$ & $11.76 \pm 0.08$ & - & $0.42 \pm 0.26$ & - & - & - & - & - \\
\hline $\mathrm{O}$ & $12.04 \pm 0.05$ & - & - & - & - & - & - & - \\
\hline $\mathrm{P}$ & $5.35 \pm 0.03$ & - & - & - & - & - & - & - \\
\hline
\end{tabular}

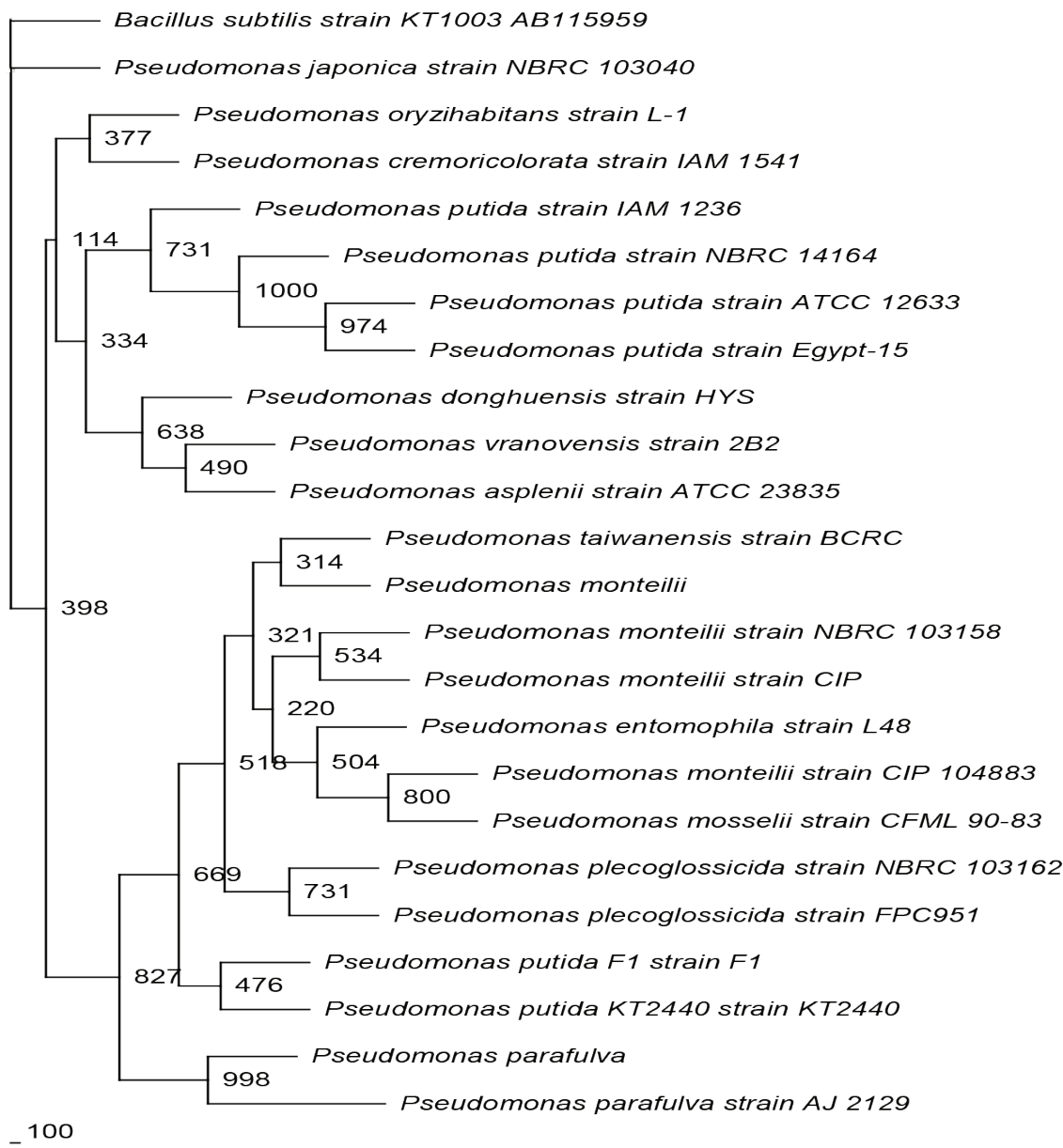

Figure 1: A neighbour-joining method phylogram based on the 16S rRNA gene sequence analysis showing the linkage between strain P. putida Egypt-15 and other reference microorganisms. Bacillus subtilis is the outgroup. The bootstrap values, which are based on 1000 re-samplings is shown at the branching points. Scale bar indicates 100 nucleotide substitutions. 
Table 3: Biochemical tests for P. putida strain Egypt-15

\begin{tabular}{|c|c|}
\hline Test & Result \\
\hline Motility & + \\
\hline Haemolysis & + \\
\hline Growth at $4{ }^{\circ} \mathrm{C}$ & - \\
\hline Growth at $41^{\circ} \mathrm{C}$ & + \\
\hline Growth on MacConkey agar & - \\
\hline Arginine dihydrolase (ADH) & + \\
\hline Alkaline phosphatase (PAL) & + \\
\hline Indole production & d \\
\hline Nitrates reduction & - \\
\hline Lecithinase & - \\
\hline Lysine decarboxylase (LDC) & - \\
\hline ONPG (beta-galactosidase) & d \\
\hline Esculin hydrolysis & - \\
\hline Gelatin hydrolysis & d \\
\hline Starch hydrolysis & - \\
\hline Urea hydrolysis & + \\
\hline Oxidase reaction & + \\
\hline Utilisation of: L-Arabinose & + \\
\hline Citrate & + \\
\hline Fructose & + \\
\hline Glucose & + \\
\hline Meso-inositol & d \\
\hline Mannose & + \\
\hline Mannitol & - \\
\hline Sorbitol & - \\
\hline Sucrose & + \\
\hline Lysine sucrose & + \\
\hline Trehalose & - \\
\hline Xylose & - \\
\hline
\end{tabular}

Note: + positive result; - negative result; $\mathrm{d}$ - indeterminate result

It is also proposed that phosphomolybdate is an intermediate substrate and have replaced molybdate with phosphomolybdate as a substrate for the Mo-reducing enzyme (Shukor et al., 2008a) resulting in the first purification of the enzyme (Shukor et al., 2014) since it was first reported in 1896 (Capaldi \& Proskauer, 1896).

\section{Carbon sources as potential electron donors to Mo-blue production}

Glucose at $1 \%(\mathrm{w} / \mathrm{v})$ was found to be the best electron donor for supporting Mo-blue production, followed by sucrose, d-mannose, lactose, melibiose, maltose,

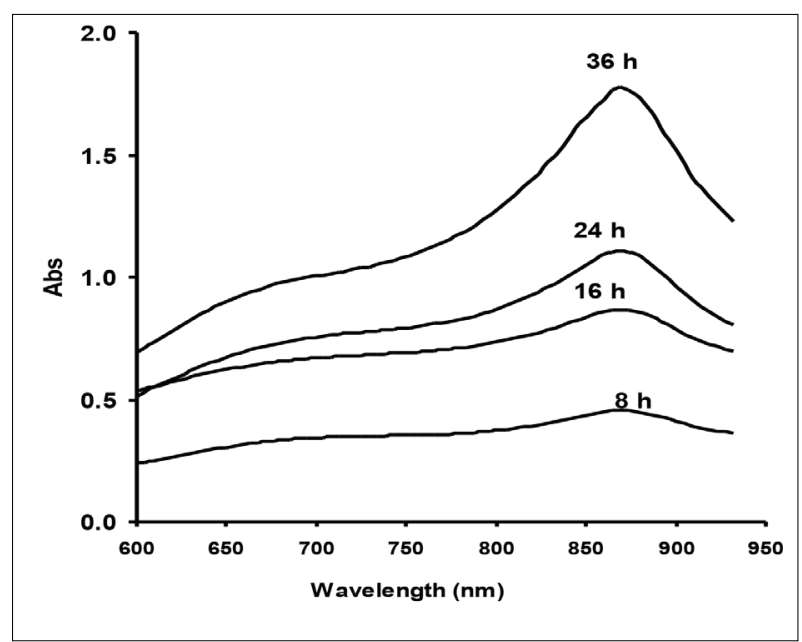

Figure 2: Scanning absorption spectrum of Mo-blue from P. putida strain Egypt-15 at different time intervals

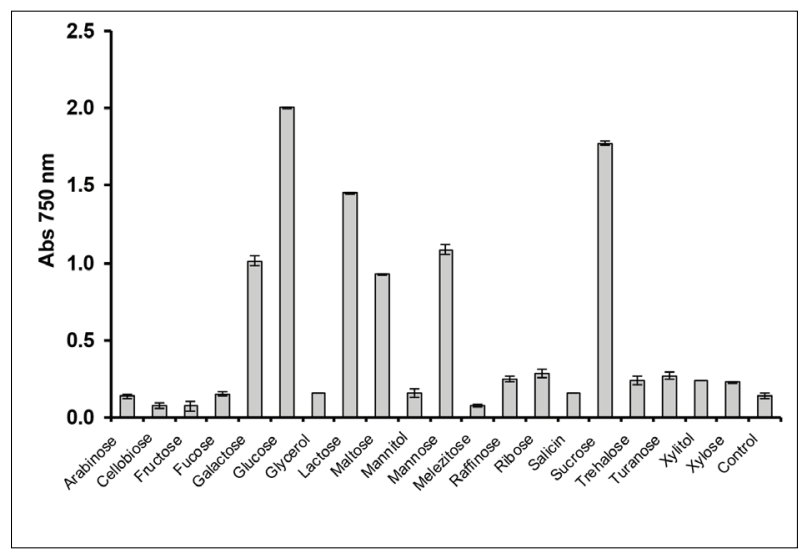

Figure 3: The effect of various carbon sources as potential electron donor sources $(1 \% \mathrm{w} / \mathrm{v})$ for Mo-blue production. The error bars indicate standard deviation of the average of triplicates

trehalose, 1-rhamnose, 1-arabinose and myo-inositol in descending order (Figure 3). Glucose was optimal at this concentration, while higher concentrations inhibit Mo-blue production (data not shown) possibly due to osmotic stress (Shukor et al., 2009b; Masdor et al., 2015). The simple glucose formate or lactate are among the most optimal electron donors for supporting metal reductions in bacteria such as in vanadate reduction (Antipov et al., 2000). In nearly all the Mo-reducing bacteria studied, either glucose or sucrose is the best electron donor for molybdenum reduction (Table 1). These carbon sources are efficiently converted to the reducing equivalents NADH or NADPH, with the latter compounds being substrates for the Mo-reducing enzyme 
(Ghani et al., 1993; Shukor et al., 2008a; Shukor et al., 2014). As some metal reduction studies have turned to the more economic substrate molasses (Zhang et al., 2008; Ahmad et al., 2013), the current work include the use of molasses as a replacement for glucose.

\section{The effect of sodium molybdate concentrations to Mo-blue production}

Both molybdate and phosphate are important for efficient Mo-blue production. Of the two, phosphate concentration is a more critical factor. The concentration supporting optimal Mo-blue production is very narrow from 2.5 to $7.5 \mathrm{mM}$, but the most reported is at $5 \mathrm{mM}$ (Table 1). On the other hand, optimal molybdate concentration varies in a large range between 5 to $80 \mathrm{mM}$. In this bacterium, the optimal reduction value for molybdate which supports optimal Mo-blue production was at $20 \mathrm{mM}$. However, the bacterium can tolerate concentrations as high as $70 \mathrm{mM}$ but the reduction capability is severely affected (Figure 4). Compared to anionic heavy metals such as mercury and cadmium, anionic heavy metals including molybdenum are tolerable by bacteria. For example, tolerance and reduction at high concentrations of vanadate, at $50 \mathrm{mM}$ has been reported (Antipov et al., 2003). The highest concentration of molybdenum in the environment is about 6,500 $\mathrm{mgkg}^{-1}$ (approximately $68 \mathrm{mM}$ ) (Stone \& Stetler, 2008). At this concentration, majority of the Mo-reducing bacteria including P. putida strain Egypt-15 are capable of converting toxic molybdenum into a less soluble and less toxic colloidal Mo-blue.

\section{PEGs as carbon sources for growth}

The optimum concentrations supporting growth on PEG 4000 for the bacterium was studied by utilising PEG concentrations between 100 and $1200 \mathrm{mgL}^{-1}$, where growth was best supported at concentrations between 600 and $800 \mathrm{mgL}^{-1}$. PEG 4000 at higher concentrations was slightly inhibitory to growth (Figure 5). Confirmation of degradation was then monitored colourimetrically. Degradation started slowly with a detectable lag period of about two days. A $75 \%$ degradation of PEG 4000 was observed on day six (Figure 6). The growth of the bacterium on PEG 4000 at $800 \mathrm{mgL}^{-1}$ was modelled according to the modified Gompertz model (Figure 7). The growth parameters obtained were, maximum specific growth rate of $2.216 \pm 0.118 \mathrm{~d}^{-1}$ and a lag period of 1.45 \pm 0.04 day. The model showed an adjusted coefficient of determination $\left(\operatorname{adj} R^{2}\right)$ of 0.995 , indicating a good agreement between predicted and observed values. The presence of a lag period in PEG degradation was also observed in other bacterial PEG degradation studies, and generally is shorter (about one to two days) under aerobic conditions and longer (> 10 days) under anaerobic conditions (Huang et al., 2005; Traverso-Soto et al., 2016). Growth on PEG was optimum at $30^{\circ} \mathrm{C}$ and $\mathrm{pH} 7.5$ (data not shown). The principal PEG-degrading enzymes under aerobic conditions are alcohol dehydrogenase, aldehyde dehydrogenase and an ether-bond splitting enzyme that progressively oxidises PEG into carboxylic acid groups, eventually producing glyoxylate (GOA),

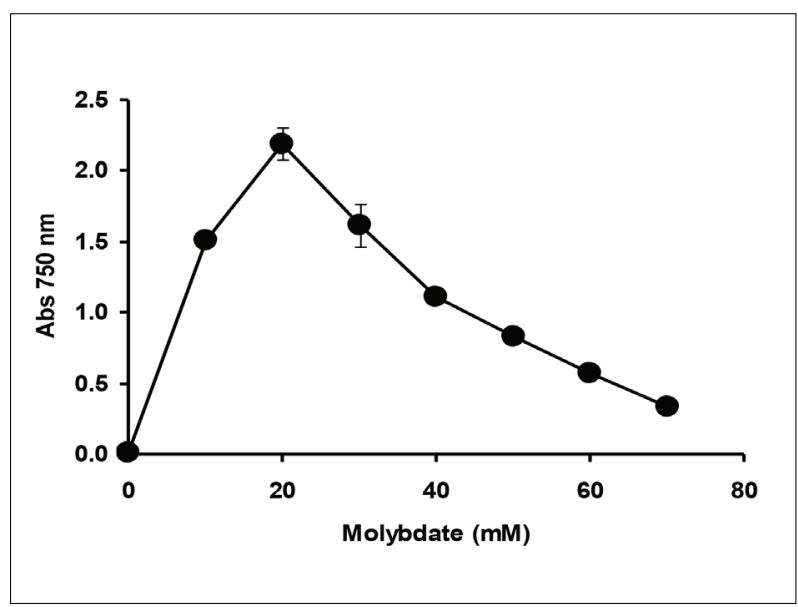

Figure 4: Mo-blue production at different sodium molybdate concentrations. The error bars indicate standard deviation of the average of triplicates

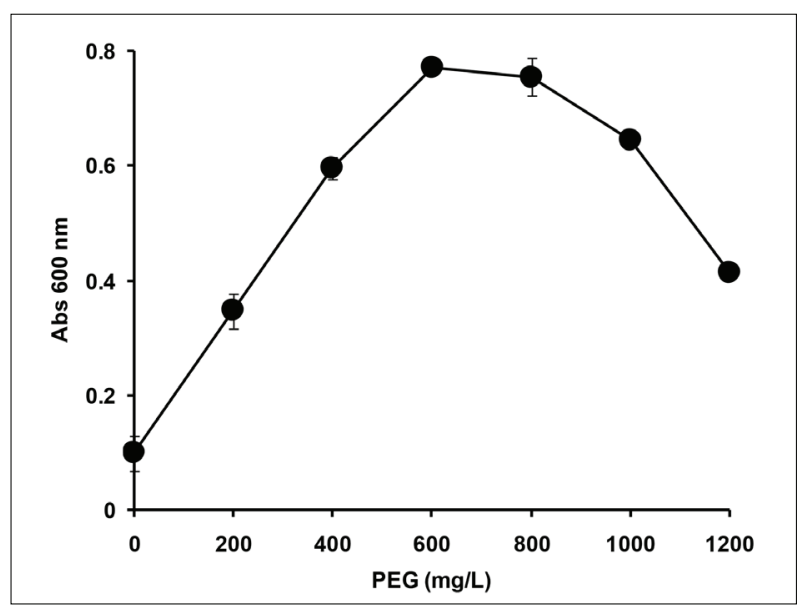

Figure 5: Growth of P. putida strain Egypt-15 on PEG 4000. Growth on PEGs was carried out aerobically in a $50 \mathrm{~mL}$ growth media at room temperature and shaken at $120 \mathrm{rpm}$. The error bars indicate standard deviation of the average of triplicates. 
which can be integrated into generic anabolic pathways starting from the glyoxylate shunt (Marchal et al., 2008; Watanabe \& Kawai, 2010).

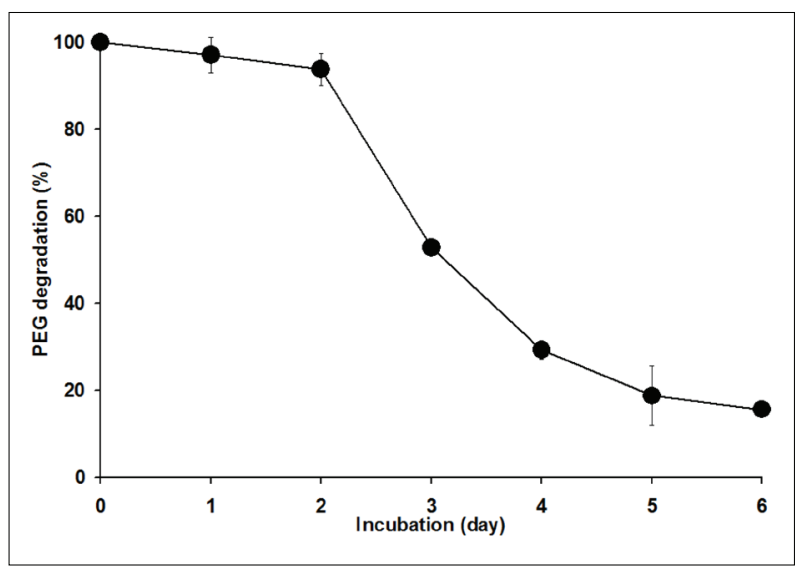

Figure 6: Percentage degradation of PEG 4000 at a starting concentration of $800 \mathrm{mgL}^{-1}$ by $P$. putida strain Egypt-15. Growth on PEGs was carried out aerobically in a $50 \mathrm{~mL}$ growth medium at room temperature and shaken at $120 \mathrm{rpm}$. PEG degradation was monitored colourimetrically. The error bars indicate standard deviation of the average of triplicates

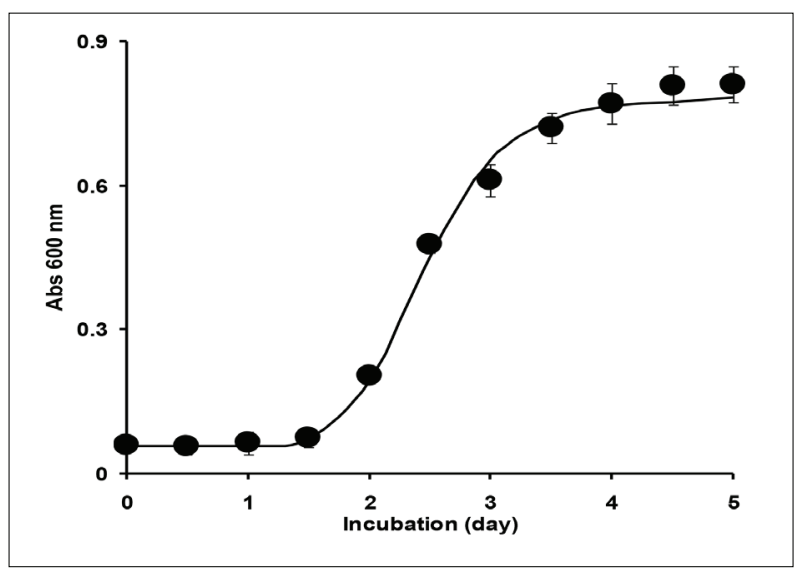

Figure 7: P. putida strain Egypt-15 growth on $800 \mathrm{mgL}^{-1}$ of PEG 4000 as modelled using the modified Gompertz model (solid lines). Growth on PEGs was carried out aerobically in a $50 \mathrm{~mL}$ growth medium at room temperature and shaken at $120 \mathrm{rpm}$. The error bars indicate standard deviation of the average of triplicates

About $80 \%$ degradation of PEG 4000 observed in this work within six days is considered achievable as the PEG chain length is relatively short and the concentration used is not high. Even higher chain lengths of PEGs and higher concentrations are reported in literature, but those require longer incubation periods. For instance, Haines and Alexander (1975) used soil bacteria to show that 10,000 $\mathrm{mgL}^{-1}$ of various PEGs from 400 to 20000 were degraded completely by 20 days of incubation. Lag periods of between two and five days were observed in correlation with an increasing PEG size. Pseudomonas aeruginosa isolated from soil can grow on PEG 20000 as a carbon source at $10,000 \mathrm{mgL}^{-1}$, but the extent of degradation was not mentioned. Degradation was carried out using resting or whole cells, and ethylene glycol was detected as a metabolite of PEG degradation. The ethylene glycol produced may be metabolised through the glyoxylate shunt (Watanabe \& Kawai, 2010).

Anaerobic degradation of PEGs was studied using a methanogenic bacterial consortium from sewage sludge at a final concentration of $5 \mathrm{mM}$ of PEG $400,2 \mathrm{mM}$ of PEG 1000 and $0.1 \mathrm{mM}$ of PEG 20000, which was equal to the final concentration of approximately $2,000 \mathrm{mgL}^{-1}$. After 12 days of incubation under anaerobic conditions, PEG 400, PEG 1000 and PEG 20000 were degraded to about 100,82 and $82 \%$, respectively. The rate of PEG degradation was approximately inversely related to the ethylene glycol number of units in the PEG molecules (Watanabe \& Kawai, 2010). In another study, Pelobacter venetianus sp. nov degraded $1,000 \mathrm{mgL}^{-1}$ of PEG 200, PEG 6000, and PEG 20000 completely, forming acetate and methane under anaerobic conditions after five weeks of incubation. Acetaldehyde was among the first metabolite detected and the glyoxylate route of PEG metabolism has been suggested (Marchal et al., 2008). Huang et al. (2005) reported that $1,000 \mathrm{mgL}^{-1}$ of PEG 600, PEG 6000 and PEG 20000 were aerobically degraded to about $85 \%$ after 5 days, $88 \%$ after 4 days, and $77 \%$ after 5 days of incubation, respectively using sludge microbes. More recently, an Acinetobacter strain degraded $83 \%$ of $1,650 \mathrm{mgL}^{-1}$ of PEG 400 within 5 days of aerobic growth at $30^{\circ} \mathrm{C}$, at $\mathrm{pH}$ between 7.2 and 8.0 (Jiang et al., 2013). Bacteria that could detoxify heavy metals and degrade xenobiotics are rarely reported. For example, in chromate reduction, a xenobiotic such as phenol can be used as an electron donor for reduction (Anu et al., 2010). Hence, the ability of this bacterium to degrade PEG and reduce molybdenum is considered novel and useful for bioremediation.

\section{CONCLUSION}

The aim of this work was two-fold; to isolate Mo-reducing bacteria with PEG-degrading characteristics from soil. A Mo-reducing bacterium with the ability to use PEG 
200, 300 and 600 as sources of carbon for growth is reported. This is the first report of a PEG-degrading and molybdenum-reducing bacterium. Characterisation of Mo-blue production from this bacterium shows that the results conform to previously published results. Growth of the bacterium on PEG was then successfully modelled using the modified Gompertz model, showing the applicability of this model to obtain growth parameters on PEG. The important growth parameters obtained indicate that PEG 200 was the best substrate while predictably, the longer chain PEG 1000 was the least preferred substrate. The ability of this bacterium to degrade PEG and reduce molybdenum is a novel and useful process for the future bioremediation of PEG as well as molybdenum.

\section{Acknowledgement}

This project was partially supported by funds from Snoc International Sdn Bhd. Acknowledgement is also due to Henry Ling of Columbia University, New York for his editorial comments.

\section{REFERENCES}

Abo-Shakeer L.K.A., Ahmad S.A., Shukor M.Y., Shamaan N.A. \& Syed M.A. (2013). Isolation and characterization of a molybdenum-reducing Bacillus pumilus strain LBNA. Journal of Environmental Microbiology and Toxicology 1: 9- 14 .

Ahmad S.A., Shukor M.Y., Shamaan N.A., Mac Cormack W.P. \& Syed M.A. (2013). Molybdate reduction to molybdenum blue by an Antarctic bacterium. BioMed Research International 2013: Article ID 871941.

DOI: https://doi.org/10.1155/2013/871941

Ahmad W.A., Wan Ahmad W.H., Karim N.A., Santhana Raj A.S. \& Zakaria Z.A. (2013). Cr(VI) reduction in naturally rich growth medium and sugarcane bagasse by Acinetobacter haemolyticus. International Biodeterioration and Biodegradation 85: 571 - 576.

DOI: https://doi.org/10.1016/j.ibiod.2013.01.008

Ali M.F., Lee Y.H., Ratnam W., Nais J. \& Ripin R. (2006). The content and accumulation of arsenic and heavy metals in medicinal plants near Mamut River contaminated by copper-mining in Sabah, Malaysia. Fresenius Environmental Bulletin 15: 1316 - 1321.

Antipov A.N., Lyalikova N.N., Khijniak T.V. \& L'vov N.P. (2000). Vanadate reduction by molybdenum-free dissimilatory nitrate reductases from vanadate-reducing bacteria. IUBMB Life 50: 39 - 42 . DOI: https://doi.org/10.1080/15216540050176575

Anu M., Salom Gnana T.V. \& Reshma J.K. (2010). Simultaneous phenol degradation and chromium (VI) reduction by bacterial isolates. Research Journal of Biotechnology 5: 46 - 49.

Campbell A.M., Del Campillo-Campbell A. \& Villaret D.B. (1985). Molybdate reduction by Escherichia coli K-12 and its chl mutants. Proceedings of the National Academy of Sciences USA 82: 227 - 231.

DOI: https://doi.org/10.1073/pnas.82.1.227

Capaldi A. \& Proskauer B. (1896). Beiträge zur kenntniss der säurebildung bei typhus-bacillen und Bacterium coli - eine differential-diagnostische studie. Zeitschrift Für Hygiene Und Infectionskrankheiten 23: 452 - 474.

Clesceri L.S., Greenberg A.E. \& Trussell R.R. (1989). Standard Methods for the Examination of Water and Wastewater. Port City Press, Baltimore, USA.

Devereux R. \& Willis S.G. (1995). Amplification of ribosomal RNA sequences. Molecular Microbial Ecology Manual (eds. A.D.L. Akkermans, J.D.V. Elsas \& F.J.D. Bruijn), pp. 277 - 287. Springer, Netherlands.

DOI: https://doi.org/10.1007/978-94-011-0351-0_19

Ghani B., Takai M., Hisham N.Z., Kishimoto N., Ismail A.K.M., Tano T. \& Sugio T. (1993). Isolation and characterization of a $\mathrm{Mo}^{6+}$-reducing bacterium. Applied and Environmental Microbiology 59: 1176 - 1180 .

Gibson A.M., Bratchell N. \& Roberts T.A. (1987). The effect of sodium chloride and temperature on the rate and extent of growth of Clostridium botulinum type A in pasteurized pork slurry. Journal of Applied Bacteriology 62: 479 - 490. DOI:https://doi.org/10.1111/j.1365-2672.1987.tb02680.x

Haines J.R. \& Alexander M. (1975). Microbial degradation of polyethylene glycols. Applied Microbiology 29: $621-625$.

Halmi M.I.E., Zuhainis S.W., Yusof M.T., Shaharuddin N.A., Helmi W., Shukor Y., Syed M.A. \& Ahmad S.A. (2013). Hexavalent molybdenum reduction to Mo-blue by a sodium-dodecyl-sulfate- degrading Klebsiella oxytoca strain DRY14. BioMed Research International 2013: Article ID 384541.

DOI: https://doi.org/10.1155/2013/384541

Huang Y.L., Li Q.B., Deng X., Lu Y.H., Liao X.K., Hong M.Y. \& Wang Y. (2005). Aerobic and anaerobic biodegradation of polyethylene glycols using sludge microbes. Process Biochemistry 40: 207 - 211 .

DOI: https://doi.org/10.1016/j.procbio.2003.12.004

Ibrahim Y., Abdel-Mongy M., Shukor M.S., Hussein S., Ling A.P.K. \& Shukor M.Y. (2015). Characterization of a molybdenum-reducing bacterium with the ability to degrade phenol, isolated in soils from Egypt. Biotechnologia 96: $234-245$.

DOI: https://doi.org/10.5114/bta.2015.56573

Jiang X., Yang Y., Peng X., Tan X., Dai S. \& Zeng Q. (2013). Screening and degradation characteristics of bacteria degrading polyethylene glycol. Chinese Journal of Applied and Environmental Biology 19: 857 - 861.

DOI: https://doi.org/10.3724/SP.J.1145.2013.00857

Kawai F. \& Yamanaka H. (1989). Inducible or constitutive polyethylene glycol dehydrogenase involved in the aerobic metabolism of polyethylene glycol. Journal of Fermentation and Bioengineering 67(4): 300 - 302.

Lim H.K., Syed M.A. \& Shukor M.Y. (2012). Reduction of molybdate to molybdenum blue by Klebsiella sp. strain hkeem. Journal of Basic Microbiology 52: 296 - 305. DOI: https://doi.org/10.1002/jobm.201100121

Marchal R., Nicolau E., Ballaguet J.P. \& Bertoncini F. (2008). Biodegradability of polyethylene glycol 400 by 
complex microfloras. International Biodeterioration and Biodegradation 62: $384-390$.

DOI: https://doi.org/10.1016/j.ibiod.2008.03.013

Masdor N., Abd Shukor M.S., Khan A., Bin Halmi M.I.E., Abdullah S.R.S., Shamaan N.A. \& Shukor M.Y. (2015). Isolation and characterization of a molybdenum-reducing and SDS- degrading Klebsiella oxytoca strain Aft-7 and its bioremediation application in the environment. Biodiversitas 16: 238 - 246.

DOI: https://doi.org/10.13057/biodiv/d160219

Neunhäuserer C., Berreck M. \& Insam H. (2001). Remediation of soils contaminated with molybdenum using soil amendments and phytoremediation. Water, Air and Soil Pollution 128: 85 - 96.

DOI: https://doi.org/10.1023/A:1010306220173

Othman A.R., Bakar N.A., Halmi M.I.E., Johari W.L.W., Ahmad S.A., Jirangon H., Syed M.A. \& Shukor M.Y. (2013). Kinetics of molybdenum reduction to molybdenum blue by Bacillus sp. strain Arzi. BioMed Research International 2013: Article ID 371058.

DOI: https://doi.org/10.1155/2013/371058

Pan L. \& Gu J.D. (2007). Characterization of aerobic bacteria involved in degrading polyethylene glycol (PEG)-3400 obtained by plating and enrichment culture techniques. Journal of Polymers and the Environment 15: 57 - 65. DOI: https://doi.org/10.1007/s10924-006-0047-y

Rahman M.F.A., Shukor M.Y., Suhaili Z., Mustafa S., Shamaan N.A. \& Syed M.A. (2009). Reduction of Mo(VI) by the bacterium Serratia sp. strain DRY5. Journal of Environmental Biology 30: 65 - 72.

Sabullah M.K., Rahman M.F., Ahmad S.A., Sulaiman M.R., Shukor M.S., Shamaan N.A. \& Shukor M.Y. (2016). Isolation and characterization of a molybdenum-reducing and glyphosate-degrading Klebsiella oxytoca strain Saw-5 in soils from Sarawak. AGRIVITA Journal of Agricultural Science 38: 1 - 13.

DOI: https://doi.org/10.17503/agrivita.v38i1.654

Shukor M.Y., Ahmad S.A., Nadzir M.M.M., Abdullah M.P., Shamaan N.A. \& Syed M.A. (2010a). Molybdate reduction by Pseudomonas sp. strain DRY2. Journal of Applied Microbiology 108: 2050 - 2058.

Shukor M.Y., Habib S.H.M., Rahman M.F.A., Jirangon H., Abdullah M.P.A., Shamaan N.A. \& Syed M.A. (2008b). Hexavalent molybdenum reduction to molybdenum blue by S. marcescens strain Dr. Y6. Applied Biochemistry and Biotechnology 149: 33 - 43.

DOI: https://doi.org/10.1007/s12010-008-8137-z

Shukor M.Y., Halmi M.I.E., Rahman M.F.A., Shamaan N.A. \& Syed M.A. (2014). Molybdenum reduction to molybdenum blue in Serratia sp. strain DRY5 is catalyzed by a novel molybdenum-reducing enzyme. BioMed Research International 2014: Article ID 853084.

DOI: https://doi.org/10.1155/2014/853084

Shukor M.Y., Lee C.H., Omar I., Karim M.I.A., Syed M.A. \& Shamaan N.A. (2003). Isolation and characterization of a molybdenum-reducing enzyme in Enterobacter cloacae strain 48. Pertanika Journal of Science and Technology 11: $261-272$.
Shukor M.Y., Rahman M.F.A., Shamaan N.A., Lee C.H., Karim M.I.A. \& Syed M.A. (2008a). An improved enzyme assay for molybdenum-reducing activity in bacteria. Applied Biochemistry and Biotechnology 144: 293 - 300.

DOI: https://doi.org/10.1007/s12010-007-8113-z

Shukor M.Y., Rahman M.F., Shamaan N.A. \& Syed M.S. (2009a). Reduction of molybdate to molybdenum blue by Enterobacter sp. strain Dr.Y13. Journal of Basic Microbiology 49: S43 - S54.

DOI: https://doi.org/10.1002/jobm.200800312

Shukor M.Y., Rahman M.F., Suhaili Z., Shamaan N.A. \& Syed M.A. (2010b). Hexavalent molybdenum reduction to Moblue by Acinetobacter calcoaceticus. Folia Microbiologica (Praha) 55: 137 - 143.

DOI: https://doi.org/10.1007/s12223-010-0021-x

Shukor M.Y., Rahman M.F., Suhaili Z., Shamaan N.A. \& Syed M.A. (2009b). Bacterial reduction of hexavalent molybdenum to molybdenum blue. World Journal of Microbiology and Biotechnology 25: 1225 - 1234.

DOI: https://doi.org/10.1007/s11274-009-0006-6

Shukor M.S. \& Shukor M.Y. (2014). A microplate format for characterizing the growth of molybdenum-reducing bacteria. Journal of Environmental Microbiology and Toxicology 2: $42-44$.

Shukor M.Y. \& Syed M.A. (2010). Microbiological reduction of hexavalent molybdenum to molybdenum blue (ed. A. Mendez-Vilas). Current Research, Technology and Education Topics in Applied Microbiology and Microbial Biotechnology. Formatex Research Center, Badajoz, Spain.

Shukor Y., Adam H., Ithnin K., Yunus I., Shamaan N.A. \& Syed A. (2007). Molybdate reduction to molybdenum blue in microbe proceeds via a phosphomolybdate intermediate. Journal of Biological Sciences 7: 1448 - 1452. DOI: https://doi.org/10.3923/jbs.2007.1448.1452

Sims G.E.C. \& Snape T.J. (1980). A method for the estimation of polyethylene glycol in plasma protein fractions. Analytical Biochemistry 107: $60-63$.

Stone J. \& Stetler L. (2008). Environmental impacts from the North Cave Hills abandoned Uranium mines, South Dakota. Uranium, Mining and Hydrogeology (eds. B. Merkel \& A. Hasche-Berger), pp. 371 - 380. Springer, Berlin, Heidelberg, Germany.

DOI: https://doi.org/10.1007/978-3-540-87746-2_48

Traverso-Soto J.M., Rojas-Ojeda P., Sanz J.L., González-Mazo E. \& Lara-Martín P.A. (2016). Anaerobic degradation of alcohol ethoxylates and polyethylene glycols in marine sediments. Science of the Total Environment 544: 118 - 124. DOI: https://doi.org/10.1016/j.scitotenv.2015.11.140

Watanabe M. \& Kawai F. (2010). Study on biodegradation process of polyethylene glycol with exponential growth of microbial population. International Joint Conference on Biomedical Engineering Systems and Technologies, BIOSTEC 2009, January 14 - 17, Porto, Portugal, pp. $145-157$.

Yunus S.M., Hamim H.M., Anas O.M., Aripin S.N. \& Arif S.M. (2009). Mo (VI) reduction to molybdenum blue by Serratia marcescens strain Dr. Y9. Polish Journal of Microbiology 58: $141-147$. 
Zhang Y., Okeke B.C. \& Frankenberger Jr W.T.F. (2008). Bacterial reduction of selenate to elemental selenium utilizing molasses as a carbon source. Bioresource Technology 99: 1267 - 1273 .
DOI: https://doi.org/10.1016/j.biortech.2007.02.048

Zwietering M.H., Jongenburger I., Rombouts F.M. \& Van't Riet K. (1990). Modeling of the bacterial growth curve. Applied and Environmental Microbiology 56: 1875 - 1881. 